\title{
Abnormal gonadotrophin release from pituitaries of muscular dystrophic mice and hamsters
}

\author{
M. Wilkinson \\ Departments of Physiology and Biophysics and of Obstetrics and Gynaecology, Dalhousie University, \\ Halifax, Nova Scotia, Canada B3H 4 H7
}

\begin{abstract}
Summary. LHRH-stimulated LH and FSH secretion was studied in hemipituitaries, in vitro, obtained from several dystrophic mouse mutants (male: $129 / \mathrm{ReJ}$-dy; $129 \mathrm{~B}_{6} \mathrm{~F}_{1} / \mathrm{J}$ dy; C57BL/6J-dy and C57BL/6J-dy ${ }^{23}$; female: $129 \mathrm{~B}_{6} \mathrm{~F}_{1} / \mathrm{J}-\mathrm{dy}$ ) and a dystrophic hamster mutant (male and female CHF-147). Without exception, pituitary tissue from dystrophic animals released significantly more FSH than did tissue obtained from controls. LH secretion was more variable; in the male mice release was inhibited, whereas in the male dystrophic hamsters secretion was elevated above normal. The female mouse mutant pituitary released more LH whereas in the female hamster LH secretion was normal.

The reduction in body weight of the mutants studied could have contributed to the observations of impaired anterior pituitary function.
\end{abstract}

\section{Introduction}

The extensive literature devoted to the investigation of muscular dystrophy emphasizes the preoccupation of most research workers' studies on nerve and muscle. However, disorders of the endocrine system in general, and of the reproductive system in particular, appear to be a recognized feature of human myotonic dystrophy (see reviews by Harper, 1979; Morley \& Melmed, 1979) and occurs in approximately $80 \%$ of men with this disease. Serum levels of gonadotrophins and prolactin varying from normal to highly abnormal are known to occur in these patients (Morley \& Melmed, 1979; Canal et al., 1982; Mahler \& Parizel, 1982; Nappi et al., 1982; Barreca et al., 1983). The hypogonadism is accompanied by damaged or fibrosed seminiferous tubules. Leydig cells, however, are often normal in appearance (Morley \& Melmed, 1979). In women the same degree of hypogonadism is apparently not present although amenorrhoea, oligomenorrhoea and early menopause have been described (Morley \& Melmed, 1979).

Investigations into the reproductive systems of mutant dystrophic mice and hamsters are rare although it is known that these animals are difficult to breed (Heiniger \& Dorey, 1980). A further brief report suggests that mice of the $129 / \mathrm{ReJ}$-dy strain demonstrate a delay in sexual maturation (Harman, Tassoni, Curtis \& Hollinshead, 1963).

In this paper we have examined the responsiveness of the anterior pituitary of mice and hamsters to stimulation with LHRH in vitro.

\section{Materials and Methods}

\section{Experimental animals}

The following male mouse mutants were obtained in groups of 6 from the Jackson Laboratory, Bar Harbor, ME, U.S.A.: 129/ReJ-dy, 129B6F $1 / J-d y$, C57BL/6J-dy and C57BL/6J-dy ${ }^{2 J}$. An 
additional group of 6 female $129 \mathrm{~B} \mathrm{~F}_{1} / \mathrm{J}$-dy mutants was also examined. All mice were 5-7 weeks old and were shipped with an equal number of age-matched controls. Male and female dystrophic hamsters (CHF-147) were obtained from Canadian Hybrid Farms, Halls Harbour, Centreville, Nova Scotia, Canada. Control hamsters were of the golden Syrian strain of the same age (5 months).

The animals were allowed to acclimatize for at least 7 days under controlled lighting conditions (lights on $07: 00-19: 00 \mathrm{~h}$ ). Food and water were freely available. We did not take into account the stage of the oestrous cycle.

\section{Culture technique}

Animals were killed by decapitation at $09: 00-10: 00 \mathrm{~h}$. The brain was quickly removed and processed as described elsewhere (Wilkinson \& Khan, 1982). Because of the cost of these animals we routinely examined pituitary tissue from animals that were also used for binding studies. Under binocular magnification the anterior pituitary was dissected free of the neural lobe and was then bisected in situ. Each half was placed on a separate stainless-steel grid in an organ culture dish containing $0.5 \mathrm{ml}$ Medium 199 (Gibco, NY, U.S.A.) supplemented with Hepes buffer $(0.01 \mathrm{M}$; Sigma, St Louis, MO, U.S.A.; sodium pyruvate $(0.001 \mathrm{M})$ and 50 Units penicillin $+50 \mu \mathrm{g}$ streptomycin $/ \mathrm{ml}$ ).

Cultures were incubated at $37^{\circ} \mathrm{C}$ in a water-saturated atmosphere of $5 \% \mathrm{CO}_{2} / 95 \%$ air for 120 min to allow stabilization of gonadotrophin release. The medium was then discarded and replaced, with or without LHRH ( $4 \mathrm{ng} / \mathrm{ml} ; 3.4 \times 10^{-9} \mathrm{M}$; Sigma), i.e. one half of each pituitary was stimulated with LHRH while the remaining half was used to determine basal (unstimulated) secretion. Each group normally consisted of 6 halves. Incubation was stopped at $120 \mathrm{~min}$ and $100 \mu \mathrm{l}$ culture medium were diluted 2 -fold with assay buffer $(0.01 \mathrm{M}$-sodium phosphate in $0.15 \mathrm{M}$-sodium chloride containing $0.1 \%$ gelatin and $0.01 \%$ thimerosal; $\mathrm{pH} \mathrm{7.6)}$ before freezing at $-80^{\circ} \mathrm{C}$. LH and FSH levels were determined by radioimmunoassay with kits from NIAMDD (LH and FSH RP-1 standards) (Wilkinson, Moger \& Selin, 1980). The sensitivities were $1.9 \mathrm{ng} /$ tube for LH and 7.8 $\mathrm{ng} /$ tube for FSH. Samples from each experiment were always assayed in a single assay to avoid interassay variability. Intra-assay variation was $5 \%(\mathrm{LH})$ and $7 \cdot 6 \%(\mathrm{FSH})$. These assays have been previously validated for use in the hamster (Berndtson \& Desjardins, 1974) and mouse (Beamer, Murr \& Geschwind, 1972). Statistical analysis was by Student's $t$ test.

\section{Results}

The results in Tables 1 and 2 indicate that the dystrophic animals were always significantly smaller than the controls. This observation is in general agreement with the report by Cosmos, Butler, Mazliah \& Allard (1980) on growth curves for the mouse mutant 129/ReJ-dy. However, pituitary gland weights were not consistently reduced except in the male and female CHF-147 hamsters. In female mice of the $129 \mathrm{~B} 6 \mathrm{~F}_{1} / \mathrm{J}$-dy strain and in the female hamsters uterine weights were abnormal. However, the reduction in weight of the mouse uterus was not significant when corrected for body weight. In contrast, the dystrophic hamster uteri were significantly enlarged. We have not observed any differences in ovarian and testicular weights between dystrophic and normal animals (results not shown).

Without exception, pituitary tissue from dystrophic mice and hamsters released significantly more FSH than did control tissue after stimulation with LHRH (Tables 1 \& 2). LH secretion was variable; e.g. tissue from $129 \mathrm{~B}_{6} \mathrm{~F}_{1} / \mathrm{J}$-dy female mice released more $\mathrm{LH}$ whereas in the males, $\mathrm{LH}$ release was reduced or unaffected compared to controls. In contrast, in the hamster, pituitaries from males released more LH whereas those from females exhibited normal secretion.

In a separate experiment, the pituitary content of $\mathrm{LH}$ and FSH was determined. In pituitaries of $129 / \mathrm{ReJ}-d y$ males $(\mathrm{N}=8), \mathrm{LH}$ values $(796 \pm 207 \mu \mathrm{g} / \mathrm{mg}$ tissue $)$ were significantly lower $(P<$ $0.005)$ than in control glands $(1272 \pm 158 \mu \mathrm{g} / \mathrm{mg}$ tissue $)$. FSH content was identical in pituitaries from dystrophic and control mice $(177 \pm 19$ and $179 \pm 16 \mu \mathrm{g} / \mathrm{mg}$ tissue respectively). 
Table 1. Body weights, hemipituitary weights and LHRH-stimulated LH and FSH release in male dystrophic mice and hamsters

\begin{tabular}{cllcc}
\hline $\begin{array}{c}\text { Mouse/hamster } \\
\text { strain }\end{array}$ & \multicolumn{1}{c}{$\begin{array}{c}\text { Body wt } \\
(\mathrm{g})\end{array}$} & $\begin{array}{c}\text { Hemipituitary } \\
\text { wt (mg) }\end{array}$ & FSH $\dagger$ & LH $\dagger$ \\
\hline Mouse 129/ReJ-dy & $10 \cdot 6 \pm 0 \cdot 2^{* * *}$ & $0 \cdot 26 \pm 0 \cdot 02^{* * *}$ & $27200 \pm 12000^{*}$ & $6400 \pm 1200$ \\
Control & $24 \cdot 0 \pm 0 \cdot 5$ & $0 \cdot 48 \pm 0.05$ & $10600 \pm 1400$ & $9000 \pm 1200$ \\
Mouse 129B6F $1 / \mathrm{J}$-dy & $15 \cdot 1 \pm 1 \cdot 6^{*}$ & $0 \cdot 54 \pm 0 \cdot 12$ & $7700 \pm 450^{* *}$ & $2300 \pm 800^{* *}$ \\
Control & $21 \cdot 6 \pm 2 \cdot 5$ & $0 \cdot 44 \pm 0 \cdot 02$ & $5200 \pm 600$ & $4000 \pm 750$ \\
Mouse C57BL/6J-dy & $16 \cdot 8 \pm 0 \cdot 7^{* *}$ & $0 \cdot 42 \pm 0 \cdot 04$ & $12500 \pm 1100^{* * *}$ & $2800 \pm 650^{* *}$ \\
Control & $24 \cdot 8 \pm 0 \cdot 9$ & $0 \cdot 54 \pm 0 \cdot 04$ & $3000 \pm 450$ & $4900 \pm 500$ \\
Mouse C57BL/6J-dy $2 \mathrm{~J}$ & $21 \cdot 7 \pm 0 \cdot 3^{* * *}$ & $0 \cdot 70 \pm 0 \cdot 12$ & $13400 \pm 1500^{* * *}$ & $2750 \pm 70^{*}$ \\
Control & $26 \cdot 5 \pm 0 \cdot 4$ & $0 \cdot 77 \pm 0 \cdot 02$ & $6250 \pm 850$ & $3400 \pm 400$ \\
Hamster CHF-147 & $109 \pm 5^{*}$ & $1 \cdot 8 \pm 0 \cdot 1^{*}$ & $1500 \pm 217^{*}$ & $2051 \pm 262^{*}$ \\
Control & $121 \pm 3$ & $2 \cdot 6 \pm 0 \cdot 3$ & $1063 \pm 58$ & $1242 \pm 250$ \\
\hline
\end{tabular}

Values are mean \pm s.e.m. for 6 observations.

† Values of $\mathrm{LH}$ and FSH are $\mathrm{ng} / \mathrm{ml} \cdot \mathrm{mg}^{-1}$ and represent stimulated secretion, i.e. total hormone released minus basal (unstimulated) values at $2 \mathrm{~h}$ after addition of LHRH.

${ }^{*} P<0.05 ;^{* *} P<0.005 ;{ }^{* *} P<0.001$ compared to control values.

Table 2. Body weights, hemipituitary weights, uterine weights and LHRH-stimulated LH and FSH release in female dystrophic mice and hamsters

\begin{tabular}{cccccc}
\hline $\begin{array}{c}\text { Mouse/hamster } \\
\text { strain }\end{array}$ & $\begin{array}{c}\text { Body wt } \\
(\mathrm{g})\end{array}$ & $\begin{array}{c}\text { Hemipituitary } \\
\text { wt }(\mathrm{mg})\end{array}$ & $\begin{array}{c}\text { Uterine wt } \\
(\mathrm{mg})\end{array}$ & FSH $\dagger$ & LH $\dagger$ \\
\hline Mouse $129 \mathrm{~B} 6 \mathrm{~F}_{1} / \mathrm{J}-\mathrm{dy}$ & $17 \cdot 2 \pm 0 \cdot 2^{* * *}$ & $0 \cdot 80 \pm 0 \cdot 04^{* *}$ & $48 \cdot 8 \pm 6 \cdot 9^{* * *}$ & $6000 \pm 1100^{*}$ & $3600 \pm 400^{*}$ \\
Control & $26 \cdot 1 \pm 0 \cdot 1$ & $1 \cdot 10 \pm 0 \cdot 10$ & $83 \cdot 0 \pm 4 \cdot 5$ & $2700 \pm 150$ & $1900 \pm 400$ \\
Hamster CHF-147 & $98 \pm 1^{* *}$ & $2 \cdot 5 \pm 0 \cdot 1^{* *}$ & $395 \pm 31^{* *}$ & $732 \pm 78^{* * *}$ & $1154 \pm 125$ \\
Control & $122 \pm 2$ & $3 \cdot 3 \pm 0 \cdot 2$ & $279 \pm 18$ & $442 \pm 56$ & $917 \pm 61$ \\
\hline
\end{tabular}

Values are mean + s.e.m. for 6 observations.

$\dagger$ Values are $\mathrm{ng} / \mathrm{ml} \cdot \mathrm{mg}^{-1}$ for stimulated secretion (see Table 1).

${ }^{*} P<0.05 ;{ }^{* *} P<0.005 ;{ }^{* *} P<0.001$ compared to control values.

\section{Discussion}

In their review of gonadal dysfunction in systemic disorders, Morley \& Melmed (1979) note that studies in patients with myotonic dystrophy show no consistent abnormalities of urinary gonadotrophin levels. However, the use of radioimmunoassay has revealed that, at least in men, basal serum LH and FSH as well as LHRH-stimulated levels are significantly elevated above normal (Harper, Penny, Foley, Migeon \& Blizzard, 1972; Febres et al., 1975; Sagel, Distiller, Morley \& Isaacs, 1975; Takeda \& Ueda, 1977). Our results for dystrophic mice and hamsters reveal some similarities. For example, LHRH-stimulated FSH secretion from hemipituitaries was consistently and significantly higher in all mutants examined. On the other hânú, wic observed no large differences in basal (unstimulated) FSH release (results not shown). This latter observation reflects an influence of our culture technique, i.e. the medium from the initial preincubation (120 $\min$ ) is routinely discarded, a step which obscures any differences in basal secretion.

Our results show that FSH release is selectively increased, because in all the mutants except the female $129 \mathrm{~B} 6 \mathrm{~F}_{1} / \mathrm{J}$-dy, $\mathrm{LH}$ output is either reduced or unchanged.

In view of the significantly lower body weights seen in all the mutants examined, studies on the effects of body mass on pituitary response to LHRH are obviously desirable. In men, loss of body weight through starvation results in a blunted pituitary response to LHRH (Klibenski, Beitins, Badger, Little \& McArthur, 1981). Similar results are seen in the rat (Howland, 1980). In women, 
severe weight loss is associated with reduced basal and LHRH-stimulated release of gonadotrophins (see for example Warren, 1977), although more recent studies suggest that submaximal doses of LHRH can give peak responses of FSH which are significantly greater than normal (Vigersky, Loriaux, Andersen, Mecklenburg \& Vaitukaitis, 1976; Travaglini et al., 1976). These studies indicate that the lower body weight of the dystrophic animals could contribute to the abnormal pituitary response to LHRH.

In conclusion, our results suggest that there are some similarities between the effects of muscular dystrophy in animals and myotonic dystrophy in man, at least insofar as anterior pituitary function is concerned.

I thank the Muscular Dystrophy Association of Canada for financial support; Dr K. M. Landymore for assistance with some of the assays; and Joan MacNeil for typing the manuscript.

\section{References}

Barreca, T., Rossi, B., Magnani, G., Sartucci, F., Arena, R. \& Rolandi, E. (1983) Nyctohemeral pattern of serum LH, FSH and PRL in patients with myotonic dystrophy. Clin. Endocr. 19, 319-325.

Beamer, W.G., Murr, S.M. \& Geschwind, I.I. (1972) Radioimmunoassay of mouse luteinizing hormone and follicle stimulating hormone. Endocrinology 90, 823-827.

Berndtson, W.E. \& Desjardins, C. (1974) Circulating LH and FSH levels and testicular function in hamsters during light deprivation and subsequent photoperiodic stimulation. Endocrinology 95, 195-205.

Canal, N., Smirne, S., Comi, G., Guidobono, F., Pecile, A. \& Caviezil, F. (1982) Study on growth hormone and prolactin secretions in myotonic dystrophy. Acta neurol. belg. 82, 178-184.

Cosmos, E., Butler, J., Mazliah, J. \& Allard, E.P. (1980) Animal models of muscle diseases. Part II. Murine dystrophy. Muscle Nerve 3, 350-359.

Febres, F., Scaglia, H., Lisker, R., Espinosa, J., Morato, T., Shkurovich, M. \& Perez-Palacios, G. (1975) Hypothalamic-pituitary-gonadal function in patients with myotonic dystrophy. J. clin. Endocr. Metab. 41, 833840.

Harman, P.J., Tassoni, J.P., Curtis, R.L. \& Hollinshead, M.B. (1963) Muscular dystrophy in the mouse. In Muscular Dystrophy in Man and Animals, pp. 407456. Eds G. H. Bourne \& M. N. Golarz. Karger, Basel.

Harper, P.S. (1979) Myotonic Dystrophy, pp. 139-149. Saunders, London.

Harper, P.S., Penny, R., Foley, T.P., Migeon, C.J. \& Blizzard, R.M. (1972) Gonadal function in males with myotonic dystrophy. J. clin. Endocr. Metab. 35, 852-856.

Heiniger, H.-J. \& Dorey, J.J. (Eds) (1980) In Handbook on Genetically Standardized JAX Mice, 3rd edn. Jackson Laboratory, Bar Harbor.

Howland, B.E. (1980) Effect of glucoprivation induced by 2-deoxy-D-glucose on serum gonadotrophin levels, pituitary response to GnRH and progesteroneinduced release of luteinizing hormone in rats. Horm. Metab. Res. 12, 520-523.

Klibenski, A., Beitins, I.Z., Badger, T., Little, R. \&
McArthur, J.W. (1981) Reproductive function during fasting in men. J. clin. Endocr. Metab. 53, 258-262.

Mahler, C. \& Parizel, G. (1982) Hypothalamic-pituitary function in myotonic dystrophy. J. Neurol. 226, 233242.

Morley, J.E. \& Melmed, S. (1979) Gonadal dysfunction in systemic disorders. Metabolism 28, 1051-1073.

Nappi, G., Martigononi, E., Sances, G., Murialdo, G., Zauli, C. Murri, L. (1982) Dynamic and chronobiological changes of endocrine indices in myotonic dystrophy. Acta neurol. belg. 82, 168-177.

Sagel, J., Distiller, L.A., Morley, J.E. \& Isaacs, H. (1975) Myotonia dystrophica: studies on gonadal function using LRH. J. clin. Endocr. Metab. 40, 1110-1113.

Takeda, R. \& Ueda, M. (1977) Pituitary-gonadal function in male patients with myotonic dystrophy; serum LH, FSH and testosterone levels and histological damage of the testis. Acta endocr., Copenh. 84, 382389.

Travaglini, P., Beck-Peccoz, P., Ferrari, C., Ambrosi, B., Paracchi, A., Severgnini, A., Spada, A. \& Faglia, G. (1976) Some aspects of hypothalamic-pituitary function in patients with anorexia nervosa. Acta endocr., Copenh. 87, 252-262.

Vigersky, R.A., Loriaux, D.L., Andersen, A.E., Mecklenburg, R.S. \& Vaitukaitis, J.L. (1976) Delayed pituitary hormone response to LRF and TRF in patients with anorexia nervosa and with secondary amenorrhea associated with weight loss. J. clin. endocr. metab. 43, 893-900.

Warren, M.P. (1977) Weight loss and responsiveness to LHRH. In Anorexia Nervosa, pp. 189-198. Ed. R. A. Vigersky. Raven Press, New York.

Wilkinson, M. \& Khan, I. (1982) Beta-adrenergic but not benzodiazepine binding sites are reduced in dystrophic mouse brain. Brain Res. Bull. 8, 547-549.

Wilkinson, M., Moger, W.H. \& Selin, L.K. (1980) An unexpected increase in pituitary sensitivity to gonadotrophin releasing hormone after treatment with porcine follicular fluid (inhibin) in immature hemicastrate rats. Can. J. Physiol. Pharmacol. 58, 220-222.

Received 18 October 1983 